mixed should be continuously boiled so that evaporation of the agent should be $\in$ ffected. It is unnecessary to say that unless this be done the therapeutic effects obtained by following the directions of the British Pharmacopoia could only be compared to some of the homoepathic doses of infinitesimal degree of dilution of which we have been hearing something of late.

1 am, Sirs, your obedient servant,

Sarile-row, Jan. 23rd, 1888 . R. J. LEE.

\section{THE HYDROPHOBIC VIRUS DESTROYER.}

To the Editors of THE LANCET.

SIRs,--I have refrained from replying to Dr. Bell Taylor's criticism of the above in your issue of Jan. $7 \mathrm{th}$, in order that I might know exactly the size and weight of the points when fiuished. Dr. Taylor refers to two-grain doses and to lozenges, but in my letter in your issue of Dec. 24th nothing is said about grains or lozenges, but only that the points will be composed of two parts, \&c. As regards risk of poisoning, I now find that even were all the available portion of a point swallowed, it would only contain one grain of corrosive sublimate, and, according to $S$ waine Taylor, three grains is the smallest known fatal dose. The nauseous taste would greatly prevent risk, even with gross carelessness, and I need not remind Dr. Taylor that policemen also carry in their pockets a far more virulent poison in the form of matches. With regard to Dr.Taylor's suggestion to use pencils of permanganate of potash, I fear the difficulty of getting such made would be great, and when made they would soon become usaless from contact with organic matter in the air and exhalations from the skin; in fact, the permanganates are, I have found, more easily rendered inhert and destroyed in this way than any other disinfectant. My chief reasons for choosing corrosive sublimate were its great strength and non-liablity to change under any ordinary circumstances or climate. Dr. Taylor's letter confirms the value of having such a remedy at hand, as does also Dr. Wilkinson's in your issue of Jan. 14th. I am, Sirs, yours faithfully,

Morecambe, Jan. 21th, $1888 . \quad$ THOS. MACCALI, M.D. \&c.

\section{REMOVAL OF FOREIGN BODIES FROM THE AIR-PASSAGES. \\ To the Editors of THE LANCET.}

SIRs,-Would you allow me to correct a mistake which has arisen in connexion with my suggestion that the margins of the tracheal wound should be sutured to the skin during operations for the removal of foreign bodies from the air-passages? This attach ment is only a temporary one, and the sutures should be divided so soon as the foreign body is removed; they cannot therefore exercise much influence on the healing of the wound. The suggestion in your remarks on this subject, that the tracheal wound should be closed by sutures after the operation, is a valuable one, if it be found on experience that they assist in the healing of the wound.-I am, Sirs, yours obediently,

Stratford-place, Jan. 25th, 1888. ThOMAS SMITH.

\section{MR, BOWLBY'S "SURGICAL PATHOLOGY."}

To the Editors of THE LANCET.

Srns,-While thanking you for the notice of my book on "Surgical Pathology" in your issue of last week, I trust you will allow me to correct a misstatement, for, if true, the paragraph to which I refer would imply considerable carelessness on my part.

Writing with reference to "Surgical Kidney." your reviewer says: "Nor can we read any reference to reflex hyperæmia or irritation as an element in the causation thereof." May I draw your attention to the fact that on the first page of the chapter on "Surgical Kidney" the first cause of the affection is stated as follows:- "The diseases of the urethra and bladder which cause surgical kidney act in more ways than one. First, it may be said that any persistent irritation of these parts is liable to cause reflexly chronic hyperæmia of the kidneys, \&c.' It is a little difficult to understand how anyone who has read the chapter could overlook so plain a statement.-I am, Sirs, yours truly,

Queen Anne-street, Jan. 23rd, 1888.

ANTHONY A. BOWLBY.

\section{VOLUNTEER MEDICAL ASSOCIATION.}

To the Editors of THE LANCET.

Sirs,-Will you be good enough to allow us to draw the attention of Volunteer surgeons to the fact that the inspection of the class now being held under the auspices of the Volunteer Ambulance Department will take place on Saturday, Feb. 18th, at 5 P.M. at the Guildhall, when the Lord. Mayor and Sheriffs will attend in state. The members of the Association and their friends will dine together at the Holborn Restaurant, at 7 P.M., the same evening after the inspection. The Council will be glad to see any army or Volunteer medical officers either at the Guildhall or at the subsequent mess meeting, and such gentlemen are invited to communicate with us at once.

We are, Sirs, yours faithfully, $\left.\begin{array}{l}\text { J AMES Cantuie, } \\ \text { Alfred Lingard, }\end{array}\right\}$ Hon. Sece.

King William Street, Strand, W.C., Jan. 23rd.

\section{MANCHESTER.}

(From our own Correspondent.)

SMALL-POX.

ONe or two cases of small-pox have recently been met with both in Manchester and in the adjoining borough of Salford; but in some of the surrounding towns, especially Stalybridge, several cases have occurred, and are attracting some attention. Several of these have been distinctly traced to infection from Sheffield, and at the last meeting of the Association of Medical Officers of Health this subject came under consideration, and a resolution was passed that all persons having occasion to visit Sheffield at present should take the precaution of being revaccinated. Whth our efficient system of notification of infectious disease, it is to be hoped we shall escape any serious outbreak of the disease. The Salford Town Council have at last decided upon a site for their new hospital for infectious diseases in Eccles $\mathrm{N} \theta \mathrm{W}$-road, though this was not accomplished without considerable opposition both within and outside the Council. It is not to be supposed that the Health Committee have come to this decision without full and mature consideration, though to an outsider it does seem that some other situation might have been found.

MEDICAL SOCTETY.

The annual meeting of the Medical Society showed a very satisfactory state of things, notwithstanding the competition and vigour of the other and younger societies. The number of members is 237 , against 249 last year, and there is a satisfactory balance of income over expenditure. The new catalogue of the library, which has been for some years in hand, is promised shortly, and not before it is required. The library now numbers 28,700 volumes, exclusive of unbound pamphlets \&c. Dr. Dreschfeld succeeds Mr. Hardie as president of the Society.

VACANCIES.

In addition to the vacancy in the chair of Obstetrics at the College, the chair of Surgery will shortly have to be filled owing to the retirement of $\mathrm{Mr}$. Lund, whose health forbids him longer taking an active part in teaching work. Few of our professors have done more for the students of the Manchester School of Medicine in the way of instruction than has Mr. Lund, both in the wards of the infirmary, in the old School of Medicine in Faulkner-street, and up to the present time within the College walls. Another favourite member of the teaching staff is about to loosen his connexion with the students. Dr. Morgan, it is understood, will before long resign his post as physician to the infirmary, by which a vacancy will be caused for an assistant physician. There will be no lack of candidates for this appointment, but rather an embarras de richesses.

DEATH OF DR. SAMELSON.

By the death of this gentleman a well-known personality in Manchester will be missed. For some two years he has been in ill-health, and at times suffered much. A political exile from his native country, Germany, he had for many years made a home here, and devoted special attention to ophthalmic work, being for some time on the staff of the 